\title{
4. Fataluku Living Landscapes
}

\author{
Andrew McWilliam
}

For each of us is one of the ancestors. And that in itself is a value to be preserved. (Cardoso 2000:21)

\section{Introduction}

In his magico-realist depictions of life and times in East Timor during the 1960s, Luís Cardoso writes about sharks as transmuted forms of ancestors: 'No one from the island was ever lost. Sometimes they lived in the sea, sometimes on the land. These cycles demanded their due if they were to continue' (2000:21). In a variety of evocative encounters, Cardoso draws attention to certain Timorese cultural notions of attachment and agency in relation to land and its living forms that are constituted in terms of spiritual and moral authority. Reminiscing about his own father's connection to revered freedom fighter Xanana Gusmão, for example, Cardoso writes:

My father never mentioned his name. He was afraid that saying it might break the charm. This was what he had always done. When he traversed rivers, he did not call out the name of the creature that lived there, the crocodile. When he crossed the sea, he never invoked the name of the master of the coral-rich waters, the shark. He thought he was still in the middle of a long crossing, that men needed a rai-nain or lord of the earth to watch over their paths. (2000:148; my emphasis)

Across Timor, engagement with the emplaced 'spirit' realm is an enduring cultural value. It forms an important component of customary landownership and connections to land among the dispersed rural populations who rely on the blessings and providence of the natural environment to secure their livelihoods. Cardoso's reference to the rai nain - the 'lord of the earth' - speaks to this cultural orientation and provides a starting point for understanding the nature of Timorese customary land relationships.

In the lingua franca of Timor-Leste, Tetun, the phrase rai na'in and its regional linguistic counterparts have a double aspect, distinguished in terms of visible and less visible forms. In its material and more mundane characterisation, the 'lord of the earth' or the 'land lord' refers to senior local clan groups and their leaders who assert a historically constituted possession of specific tracts of land 
and its constituent living forms. Typically, the status of 'lord of the land' is one founded on narrative claims of mythical precedence as first settlers or preeminence as warrior usurpers over defined localities.

All villages across Timor-Leste reflect complex histories of engagement and alliance between rai na'in groups. These clans make up indigenous political communities and order their affairs around a composite collective local authority. Typically too, senior rai na'in clans of local political domains are represented in the public sphere by spokespeople known as lian na'in (lord of the words): accomplished ritual speakers who serve as authorities over land matters within their respective jurisdictions and adjudicators of moral behaviour (for example, Meitzner Yoder 2003:19-20).

The authority and entitlement of rai na'in clans and their constituent agnatic membership, however, rest on a second order of relationship to land that is constituted in spiritual form. Assertions of ownership of customary lands are simultaneously statements of claim about particular relationships and obligations towards the 'spirit' community that resides and is believed to enliven the land. It is this understanding that accords the idea of the rai na'in a double aspectnamely, a human and visible form embodied in the living senior representative of the clan community of owners, and a second mostly invisible realm that comprises autochthonous emplaced 'spirit' entities of the land itself together with the collective ancestral shades of the living owners.

In this cultural construct, the living community of landowners together with their affinal allies who are granted land entitlements through marriage alliances maintain a continuing relationship of sacrificial commensality with their living domain. In exchange for placating and feeding emplaced 'spirits' of the land, the living community ensures access to its abundant blessings and protection-a relationship I have previously described as one of consubstantiation where living and 'spirit' forms are mutually constituted and strongly interdependent (McWilliam 2007b).

It is within this relationship of mutuality between the visible and invisible worlds that the continuing local legitimacy of the rai na'in - the 'lord of the land' - might be said to reside. Characteristically, the relationship is described in classificatory terms as hot (manas) with 'sacred' and dangerous properties - a term glossed in Tetun as lulik, and one that evokes a complex range of attitudes from fear and awe to familiarity and comfort (see Forbes 1989; McWilliam 2001; Pannell 2006). ${ }^{1}$

1 British Naturalist Henry Forbes, who visited Timor in 1882, described the luli in terms of a sacred institution, a taboo practice (1989:442), something awesome and protective in times of war (p. 446) and something that invoked fear of its vengeance if transgressed (p. 443). 
In this chapter, I explore something of the distinctive shape and character of this doubly constituted notion of the 'lord of the land', which arguably reflects a deep orientation to binary classification and the ontological basis of diarchy as a characteristic of Austronesian ritual polities. While it finds broad application across the range of ethno-linguistic communities of Timor (see Bovensiepen, this volume; McWilliam 1999, 2002:103) and the Austronesian cultural sphere more generally, here I wish to focus on the concept as it informs contemporary practice among Fataluku communities in far eastern Timor. For Fataluku, local concepts of cultural sovereignty and natural resource entitlements are necessarily mediated and actively reproduced through the indeterminate agency of the spiritual realm. The association has retained its vitality and importance in Fataluku society during the long years of colonial rule and into the postindependence period. If personal beliefs in the spiritual realm are held unevenly among the population, and the influences of Catholicism and modernity have been at work here, they nevertheless form an integral legacy of the cultural domain across Fataluku living landscapes.

As a final introductory comment, I note that my use of the terms 'spirit' and 'spiritual' in this chapter is intended to refer to the complex range of largely invisible or only temporarily embodied entities in the landscape with which people engage and through ritual means enjoin, placate or invoke blessings. Use of the term 'spirit' has been criticised variously for its allusion to outmoded explanations of animism, for its tendency to mask or diminish the nature of the very complex it seeks to reveal, its religious implications as something disembodied, non-material or transcendental (see Harvey 2006), and as an inappropriate application of Western body/spirit dualism (Bird-David 1999). In the absence of a succinct and satisfactory alternative, however, I find it a useful gloss for describing the kind of elusive yet tangible phenomena discussed in this chapter. I find its replacement with forms of non-human 'persons' (Harvey 2006) or 'superperson' (Bird-David 1999) unsatisfactory and confusing. My concession is to use the term 'spirit' in inverted commas to denote that it glosses the nature and reality of a broader set of relationships that living human society maintains with other forms of being, whether other-than-human or ancestral in nature. The argument is partly semantic: if animism can be rehabilitated in new and productive ways, so can the definition and concept of spirit (see Peterson 2006 for a critique of these notions). 


\section{Land and Life in Lautem}

Fataluku society forms the main ethno-linguistic community of Lautem ${ }^{2}$ district in far eastern Timor-Leste (sometimes referred to as Ponta Leste), with an estimated population of about 40000 people (National Census 2004). ${ }^{3}$ A Papuanlanguage-speaking peoples, Fataluku society nevertheless shares many cultural features with their Austronesian-speaking neighbours (McWilliam 2007a). The majority of residents are farmers and pursue forms of near-subsistence swidden agriculture combining seasonal maize and secondary food-crop cultivation with smallholder livestock production. Buffalo (arapou) and pigs (pai) hold important and reciprocal roles in local livelihoods, especially in the complex ceremonial exchanges that mark life-cycle transitions and the making and remaking of social alliances.

Hamlet settlements are dispersed and these days cluster along access roads or around administrative centres - a legacy of Indonesian times when tight security policies prevailed. Many people also maintain simple houses in their swidden gardens following the pattern of earlier times when forest settlements (known as $o t u)^{4}$ tended to be scattered and more mobile. Extensive use is also made of fallowed forest areas and coastal shorelines foraging for wild foods and other livelihood resources (see Pannell, this volume).

In the years since the withdrawal of the Indonesian Government from TimorLeste in 1999 and the subsequent attainment of national independence, Fataluku communities have been busy with the task of rebuilding their lives. The loss of Indonesian subsidies and services along with the collapse of the formal market economy have fostered a renewed community focus on self-reliance and the restoration of a range of customary relationships that was previously curtailed and constrained under Indonesian military rule. These practices include the revitalisation of ceremonial exchange economies, a return to indigenous religion and a renewed interest in customary land tenure and assertions of landed authority at a time when formal systems of land administration have yet to be promulgated through national legislation.

2 A corruption of the phrase Lau tein $(u)$ : 'sacred' woven cloth.

3 The main population area of Fataluku speakers lives in the subdistricts of Lautem, Tutuala and Fuiloro. In Luro and Iliomar subdistricts, the main population groups are Sa'ané (a dialect of Makassae) and Makalero speakers respectively.

4 The term Otu refers to a settlement site with a varying number of constituent households usually comprising a core group of agnatic kin and their affines. 


\title{
Fataluku Lords of the Land: The visible realm
}

\begin{abstract}
Lautém terrified intruders. It was a land of proud, passionate men, all speakers of Fataluko. They guarded their honour with swords which they always carried with them and were quick to use. There were tales of vendettas dating back hundreds of years. (Cardoso 2000:46)
\end{abstract}

A fundamental social institution that informs the organisation of Fataluku society is the ratu - a term I define as a dispersed, exogamous, paternal 'house of origin'. Ratu membership typically includes male agnates, their in-married spouses and children. The unity of the group is articulated through affiliation to common male ancestors, ${ }^{5}$ narrative myths of settlement and mobility, along with shared ritual obligations and access to inherited common property in clearly defined localities. Social and personal identities of people are intimately connected and reproduced through the discursive frames of ratu ritual practice and relation. These markers of affiliation and differentiation are expressed through inherited names, ritual knowledge and commensality, especially of sacrificial meat (leura tei), as well as food proscriptions, textile designs and various clan-specific heirlooms and ancestral regalia. Periodically, members of the ratu gather in ritual commensality to celebrate their common origins at sites of mythical significance.

The settled landscape of Lautem proliferates in named resident ratu groups and their scattered constituent households. ${ }^{6}$ Their frequently contested histories of segmentation, dispute and dispersal across the landscape provide the basis for varying degrees of alliance and cooperation. Normative social relationships beyond closely related agnatic households are formulated around continuing and complex systems of exchange and marriage between the exogamous ratu. For this reason, all Fataluku settlements in Lautem form composite communities of intermarrying ratu households whose relationships are structured around shared narrative histories of mutual assistance and interdependency. ${ }^{7}$ This feature is

5 Female ancestors of the ratu may hold a significant place in the oral histories of the group but the general emphasis remains on the continuity of the paternal progeny.

6 There are dozens of named ratu in Lautem (with names such as Cailoro Ratu, Latuloho Ratu, Naja Ratu, Lavera Ratu and so on), and while clearly finite in number, precise enumeration is complicated by contested views over the status and standing of different groups. I have recorded at least 60 named clans, many of which have split off from other 'sibling' ratu in the distant past. Historically, when a number of households separated from the main clan group and settled elsewhere, they sometimes took on the name of the locality in which they settled for their ratu. Many groups also veil or mask the 'real' names of their origins.

7 Ratu clans form the most senior and highest status of three broad categories or castes of person in Fataluku society, distinguished by the terms ratu, paca and akanu. The term paca represents a subordinate but complementary 'younger sibling' (noko) grouping who maintain a close relationship and long-term alliance with their ratu counterparts. The origins of the ratu and paca divisions are obscure and much debated. Here, I would simply note that paca groups typically maintain long-term alliances with their classificatory ratu elder siblings ( kaka). A third category or caste of person and the lowest in social status is akanu or slaves whose ancestors were former war captives or who were bankrupted into slavery in Portuguese times. Conventionally, 
even more pronounced today as a result of the population-concentration policies initiated under Portuguese colonialism following Japanese occupation during World War II and intensified under Indonesian rule (see McWilliam 2007b). But for every existing or former settlement area across the Fataluku culture-scape, there is typically one ratu group that is accorded the senior status of mua ocawa or 'lord of the land'. This title acknowledges the authority and relationship of the principal landowning ratu to a defined landed jurisdiction and honours their precedence or mythical 'first-settler' status in the area. As elsewhere in Timor, here, the Fataluku title mua ocawa also contains a double aspect that differentiates the living members of the senior landowning group from their invisible 'spirit' counterparts - sometimes distinguished by the extended form mua hocavaru (land and lord). ${ }^{8}$

More specifically, in Fataluku ritual speech, the formal title of the senior landowning ratu is expressed by the phrase

Mua caovele ocawa Land head skin lord

Horo caovele ocawa Gravel head skin lord

The term horo in this binary representation refers to the widespread distribution of coralline rubble across the region - a feature of the karstic limestone character of the landscape and a material commonly used to construct sturdy stone fences that mark food-garden boundaries. Collectively, the reference speaks to the Fataluku distinction between the 'body' of the earth and its covering 'skin' (vele). By inference, people may cultivate the skin (vele) of the land for food crops or hunting, but only the 'lord of the land', the mua ocawa, asserts a preeminent authority over the whole of the land in question. This is an enduring relationship reaffirmed through social consensus and a sustained sacrificial engagement. It also means that in a general sense all land across Lautem is held as forms of common property by the collective members of various discrete ratu groups who share 'one blood, one serum' (vehe ukani, ahi ukani). Their territory is said to form part of the 'sacred land and the sacred garden' (mua teinu ho pala teinu) of the ratu - a phrase that links contemporary living members to the earliest settlements of their ancestors and the long history of cultivation and food production that has provided life and sustenance to the clan and its allies over generations (McWilliam 2007b).

intermarriage between these levels is proscribed, and although modernist pressures over recent decades have challenged the legitimacy of these cultural categories, they continue to inform social and political relations both within and between community settlements. Publicly identifying someone's caste status is considered bad form and these days most people will assert a more generic membership of a ratu group while denying connection to paca or akanu status.

8 In this chapter, as an orthographic convention for Fataluku words, the letter ' $c$ ' is pronounced ' $c h$ '. The pervasive use of ritualised parallel speech is a common linguistic feature of the language. 
The particular pattern of ratu landownership and the comparative size of their respective territories derive ${ }^{9}$ from the mythical origins of settlement and the inherited entitlements of ancestral spatial practices. Adjustments and modifications reflecting complex and mobile histories of inter-group warfare and shifting political alliances have also informed boundary-making processes over time. Today, the limits of these ancestral common-property lands are more or less fixed, their meandering edges marked variously by sacrificial alter posts (ete uruha'a), ridge lines or prominent marker stones, as well as by crumbling stone walls of fallowed garden sites, creek lines and other topographic traces. The knowledge of boundaries (varuk ho fetil) ${ }^{10}$ is retained as part of the heritage of the ratu agnatic community, especially the senior male affiliates and customary leadership of the group (referred to as laficaru or, in their role as ritual speakers, by the parallel phrase hoponocawa :: luku-lukunocawa [master of chants, master of words]). ${ }^{11}$

With established dominion over the land, founder groups assert a temporal and political precedence in relation to subsequent settlers whose subsidiary claims are framed in relation to the established 'lord of the land' (mua ocawa). These later arrivals - groups seeking refuge from inter-clan warfare or banishment from other lands - ally themselves to the resident owners and gain access to favourable marriage arrangements, settlement sites and arable land. One way Fataluku describe the protective, nurturing role of the mua ocawa is to refer to them metaphorically as the nalu lafae, the great mother, who, in the marriage of their daughters to immigrant husbands, provide the susu ho ami (white sap and milk) that enables their households to prosper and grow. In a real sense, wife-givers 'give life' (lauhana mina) to their in-marrying affines. In Fataluku marriage terminology, this relationship is expressed as one between the progenitors, ara ho pata (base and post, trunk and stem), and their progeny, tupurmoko (little women), which establishes lifelong asymmetrical alliances of mutual obligation and exchange.

As in-marrying affines, and cultivators of the skin (vele) of the land, they are said to enjoy the mina ho vai'a (oil and fat) of the land-a distinction expressed in formal speech as:

\footnotetext{
9 A definitive survey of ratu land boundaries, although still feasible, has never been undertaken.

10 A parallel speech form that combines the idea of a boundary and visible border markers.

11 A further title is that of 'he who sits in front of the sacrificial hearth' (acakaka emer miré). Conventionally, all ratu recognise an internal differentiation based on the birth order of sibling lineages. Namely, first born (moco kaka), who take priority and political precedence, middle born (moco ulu penu) and last born (moco vehula). Ratu leadership may emerge from any of the sibling groups, but conventionally the first-born lineage (moco kaka) is accorded seniority.

$12 \mathrm{Ami}$ is the Fataluku word for breast milk while susu is the name given to the white sap of the forest fig tree (hama) that grows in abundance in the lowland forests and is often the site of ritual veneration (somewhat ironically given that susu [susubeen] is the Malay/Tetun term for milk).
} 
The relationship is also conveyed in the Fataluku botanical trope between those who are 'rooted' in place (ara ho pata) and those who receive the flowers and fruit of the land (icipi imana) and build on the base established by the mua ocawa. ${ }^{14}$ But the precise arrangements over access and use are dependent upon specific histories of negotiated agreement and alliance. There are numerous narratives that describe the multiple circumstances under which wandering groups have sought and found refuge with landowning clans. ${ }^{15}$ In generations past, for demographic reasons as much as any other, migrant male settlers could be granted permanent or nested ownership rights in land by the resident mua ocawa. In the process, they become 'lords or masters of their own garden areas' (pala ocawa) and permanent resident allies, able to bequeath land to their children and fully participate in the community exchange economy. Collectively, the subsidiary allied households that reside with the mua ocawa group may be referred to as $i$ namaunu: $i$ tara maunu (those who come later: those who have recently arrived) or olo comaunu: aca comaunu (literally: 'birds' coming from afar). This category includes both allied ratu households with longstanding relationships of marriage exchange and newcomers with shallow histories of engagement. ${ }^{16}$ But, ever conscious of transgressing cultural sensitivities and the fines that may accompany them, by convention, they are referred to variously as 'sisters and children' (leren ho moco), 'affines and friends' (vaian ho paienu $:: \operatorname{lan}[u]$ ho tava) - a relationship that may not be arbitrarily severed without retributive consequences. Conversely, the subsidiary houses remain conscious of the need to respect the authority of the mua ocawa and to inform and consult them on significant matters dealing with the land.

If the local 'lord of the land' (mua ocawa) is positioned at the apex of a residential complex of subsidiary households and affinal segments of in-marrying origin groups, their capacity to sustain this pre-eminent position is only in part founded on their political authority and settlement precedence. It is also constituted through an enduring bond and ritual engagement with the inspirited landscapes to which their ancestors negotiated, through ritual sacrifice with other-thanhuman forms, into an enduring sovereignty over the land.

13 The reference also alludes to the obligatory gifts of food offered by wife-givers (omara) to their affines known as ore fai - portions of cooked pork for which they reciprocate with buffalo meat, known as leura.

14 A'a lalune (to make the base), a'a ca'unu (to layer or stack on top).

15 For illustrative purposes, I was given the example of the person who builds a house and when visitors come they are allocated a room, but if they then want to extend or change the structural arrangements they need to consult with the house owner.

16 In more recent times, the practice of allocating more or less permanent land entitlements to in-marrying affines is now less common as land availability has declined with population growth. 


\section{Inspirited Landscapes: The invisible realm}

For most Fataluku, the experience of the 'spirit' domain is part of the lived reality of social life. They refer to this ever-present though largely invisible presence by the generic term tei (sacred, taboo, prohibition) or teinu (pl.) - a concept that combines moral authority and protective familiarity with elements of dangerous uncertainty and retribution. That which is tei or accorded the properties of tei must be treated with caution, respect and ritual restraint. ${ }^{17}$

The concept of tei extends to a wide range of spiritually charged locations across the land, to certain forms of behaviour, the consumption of sacrificial meat (leura tei, ipilu tei), forms of avoidance relationships (nita tana tei), ${ }^{18}$ the sanctioned names of origin ancestors and ratu-specific knowledge of healing spells, sorcery (vetiku, hupia, kori) and protective invocations (lukun teinu: hopon teinu). As Pannell and O'Connor (2004:2) have argued, 'the notion of tei is positioned in the centre of a discourse which explores the often perilous limits of sociality', where the idea of the sacred or of sacrality expresses the inherent ambiguity of power and lies in the indeterminate space between blessings and threats, malevolence and benevolence.

Within a broadly Catholic framework under God (uruvacu: moonsun), Fataluku make a distinction between two broad classes of tei-namely, between a set of autochthonous beings of the land that is conceived of as predating human settlement; and tei that are created or emplaced by human action including ancestral shades and places in the landscape that memorialise ancestral spatial histories. ${ }^{19}$ This distinction also informs the idea of an inspirited landscape that combines a notion of engaging pre-existing and emplaced 'spirit' forms along with active processes of inspiriting as a means of religious transformation of the landscape. The latter point includes legitimating processes of clearing and cultivating the soil, hunting and utilising its resources, being born and dying in the land, all of which contribute to the conversion of the country from the strange to the familiar, from 'other lands' to 'our lands'. ${ }^{20}$

17 People often carry with them small bundles of charms (ete lari: tree root) that are designed to protect them from unwanted threats or spiritual attack from witches (acaru) or other dangerous influences.

18 This phrase might be glossed as 'our hands are tei' and refers to a situation where two groups engaged in past feuding in which members were killed and who have not undertaken subsequent ritual peacemaking. For this reason, they avoid situations of sharing food and other forms of sociality because of the risk of severe spiritual sanction associated with the blood curse.

19 There is a degree of transformational blurring and indeterminacy in this division. Some ratu recognise their ancestral origins to derive from animals or creatures that inhabit the region — sharks, crocodiles, dolphins and so on - which take on some of the attributes of totemic significance and association.

20 I have adapted the term 'inspiriting' from the anthropologist Basil Sansom, speaking on the nature of Australian Aboriginal land connections and migrations (1993:29). The idea supports Pannell's observation that 'the foreign is rendered familiar through the presence and experience of tei' (2006:8). 
For Fataluku, over generations of interaction and engagement, of ritually feeding (fané) and placating the wild, unrestrained nature of tei, the senior landowning group, the mua ocawa, confirms their entitlement and authority over the land in question. As a Fataluku colleague described this relationship, 'the mua ocawa tei is wild, jealous and dangerous and only the [human] mua ocawa has the authority and right to manage it'. There is, some say, little distinction between the living mua ocawa and their invisible counterpart. The latter form is at times able to take on the visible appearance and substance of their living counterparts. They are mutually constituted, consubstantiated or, as one Fataluku colleague put it, 'there is no clear boundary between the mua ocawa that can be seen and the one that can't'. That is why people honour and respect the 'lord of the land' and seek their permission to reside on the land and utilise the abundant resources of which they are custodians. ${ }^{21}$

In a similar fashion, Pannell has described the autochthonous being who inhabits the cliff site of Ili Keri Keri in Tutuala as one 'which, like all other beings [who] occupy pre-existent tei places within the Fataluku landscape, has a ritual name considered hot and dangerous and known only by (the generic term) "lord of the land" from Tutuala Ratu (mua caoveli hocawa)' (Pannell 2006:11).

The presence of the spiritual 'lord of the land' might manifest itself in a variety of living forms including pythons (nana), green tree snakes (cuale'u::pelikafu) or the mythical aka, which can appear as part-human-part-snake (see King 1963:151). Crocodiles (lavei), dogs (iparu), species of birds (olo) or even insects (bees: wani, and a species of cricket: napa) might also be recognised. In any specific bounded jurisdiction, one or two of the native fauna might be construed as the senior 'lord of the land', the tei ocawa (lord of the tei) over the living forms in its domain.

It is said the wild tei of the land (mua cupenu) are calmed or 'tamed' (tei ma'a varin pai) through the actions of their human counterparts. Sacrificial offerings of blood, offal, rice and palm liquor with appropriate invocations (lukunu tei) render them amenable to the control of the living lords of the land. ${ }^{22}$ The formulaic words and language of address to the tei are the property of the senior landowning group, which secures the protection of those who legitimately reside within their lands. But the nature of the invisible mua ocawa is capricious and demanding, and they might turn on their living custodians when neglected or addressed incorrectly. As ever, there is a high degree of indeterminacy in

\footnotetext{
21 When farmers open new food gardens (pala miri), they perform a small divination known as minin fai, which is undertaken to ensure there are no issues that might hinder the growth and harvest success of the gardening activity. The ritual is simultaneously an acknowledgment of their permission to do so.

22 Hicks' argument about 'snagging divinity' and the dynamic interdependency, even parity, between the realm of humanity and the divine is relevant here (see Hicks 2007:51). He cites with approval the early position of Hubert and Mauss (1964:91) that 'not only is it in sacrifice that some gods are born, it is by sacrifice that all sustain their existence'.
} 
relation to engagement with the tei. The middle of the day, when the sun is hot and strong, is considered a dangerous time when tei beings appear and move about. People are encouraged to be alert to signs of their presence or actionunusual noises, movements or bodily sensations - and to avoid places where malevolent entities are said to reside. The occasion of a whirly-whirly (refutu), for example, might signal the presence of the tutelary 'spirit' (mua hocawaru), and one should step aside and let it pass. As a Fataluku interlocutor has put it, 'nature still has authority over us', and this attitude facilitates a range of cultural practices designed to placate that which is potentially malevolent and to invoke its assistance in times of need ( $i$ tei lira fai: to invoke the tei). As the custodians of an abiding relationship with the living environment, the senior representatives of the living lords of the land have the inherited responsibility of managing this relationship on behalf of their co-resident affines and allies.

In this chapter, I do not intend to explore the ontological foundations of Fataluku cultural ideas about the nature of the living world, except to comment that, in my view at least, inspirited landscapes of Lautem are inhabited, not conscious. The land and its topographical features - its rocks and trees, flora and fauna - are not sentient, as has been argued of some other indigenous traditions (for example, Poirier 2005; Viveiros de Castro 1998). ${ }^{23}$ Rather, I would argue for a living realm that is construed in symbolic and metonymic forms and which serves as a medium for addressing the uncertainties and contingencies of social life. Fataluku relationships to land are complex and inflected with high levels of sentiment and inscriptions of meaning-'analogous identification', in Pederson's terms (2001:416). As forms of externalised moral authority, the inspirited landscape is understood to be inhabited by an indeterminate set of other-than-human and formerly human identities that might be recognised and manipulated through processes of discovery. These processes of recognition are learned reactions and responses to cultural expectations and Fataluku society has developed an elaborate complex of divinatory diagnostic techniques to interpret sources of affliction and resolve otherwise unexplained events. In this context, people often turn to trusted diviners and healers (in formal speech, known as $i$ na haran :: i na lolon navarana) to interpret and identify remedial strategies for addressing and resolving the arcane and often deleterious impact of inspirited forms on their lives. ${ }^{24}$

The living world of tei includes a second corpus of potent shades constituted in ancestral form. In ritual speech, the ancestors are called the umun ho upenu

23 The issue, however, remains open to interpretation and the whole matter is somewhat ambiguous as Fataluku sometimes appear to impute agency and awareness to the land itself.

24 An example offered to me was people who might have participated in the murder or death of others during the Indonesian period of oppression, but who did not divulge their complicity or sin. In time, they might be 'caught' by the shade of the victim seeking revenge, possibly appearing in the sudden death of children or an economic disaster for the household. 
(those who are deceased and those who are no longer), and there is a high value placed on the memorialisation and sustained ritual engagement with clan ancestors, conventionally addressed as calu ho papu. ${ }^{25}$ Through prayer, invocation and sacrificial feeding (fané), the ancestors are urged to provide blessings and protection ${ }^{26}$ for their descendants, to ward off illness and heal the sick, to bring abundant harvests and healthy babies, to restore reputations and alleviate suffering. Even in times of economic hardship, Fataluku households put substantial resources towards commemorating the death of relatives and the construction of large, elaborately decorated concrete graves.

The majority of Fataluku communities locate their ancestral origins in the long-range sailing exploits of their forebears who made landfall on the coast of Lautem in their oceangoing perahu (F: loiasu), leaving mythologised inscriptions of their settlements across the forested landscape. These marks and signs of ancestral activity are variably expressed, but typically include the following elements: carved sacrificial alter posts (ia mari tulia, ancestral footprints) located around the coastal fringe, which identify places where mythical ancestors made landfall and established their first settlements; ${ }^{27}$ specific ancestral 'stone boats of origin' (loiasu mataru) that beached on Timor and became lodged in the landscape, now manifest as fossilised limestone outcrops; ${ }^{28}$ and numerous overgrown former hilltop settlements (lata paru and lata irinu) or stone-walled forts (pamakolo and laca), often containing massive stone graves (calu lutur $[u]$ ) with spaces for ceremonial enactment (sepu). Collectively, these sites mark the historical and spatial imprint of ratu ancestral activity across the landscape. Each might provide a focal point for ritual invocation in the hope that blood sacrifice and prayer can resolve grave misfortunes afflicting members of the living origin group, or celebrate the blessings of their abundance. These early and old sites of ancestral presence are reputed to be the most powerful in terms of their restorative or influential effects. Their seniority, it is said, gives them the authority to 'assemble' a wider group of ancestral shades. ${ }^{29}$ Powerful ancestral sites are also, however, fraught with risk where errors in ritual performance and narrative forms of address carry heavy sanctions such as illness and even death

25 The phrase is a collective reference to the corpus of ancestors of the ratu. It refers specifically to the names of the second and third ascending generations of male ancestors (grandfather, great-grandfather).

26 The protective agency of the ancestors is expressed in the phrase ufur(o) ho namu utupé, to protect (our) body and person.

27 The statement elides a complex variety of mythical knowledge and belief. Some of the founding ancestors (known generically as $\mathrm{Cal}[u]$ arafura) are said to have arrived in the guise of sea creatures: crocodiles, dolphins, sharks or stingrays. Others rode on their backs or walked along the seabed. Each group has its own narrative myths of origin and arrival.

28 Carved wooden alter posts and naturalistic figurines (known generically as ete uruha'a or sikua) that represent ancestral figures or sites for sacrificial invocation to ancestors.

29 In death, the shades of the newly deceased are enjoined, through forms of ritual chanting known as sau and nololo, to travel back to the origin settlements and join the collective ancestry of the ratu community. As Campagnolo (1975:75) has observed, Fataluku might sometimes say of the death of someone that 'they have gone to plant coconuts in the land of the first village'. 
for practitioners. For that reason, Fataluku generally rely on the knowledge and ritual skills of their leaders (laficaru, luku-lukunocawa) to determine and conduct the necessary invocations at the more potent origin sites of veneration. At other times in the absence of good reason, people tend to avoid approaching iconic ancestral sites or do so with caution and care, especially those associated with other clans. ${ }^{30}$

For spiritual comfort, most Fataluku households rely on prayer and invocation to their immediate household ancestors through the medium of ritual hearths (acakaka or lafuru tei). There structures of invocation are maintained within the domestic house itself. Culturally, it is expected that a newly married couple will install an acakaka, the initial burning embers of which are brought from the hearth of a senior agnatic relative in a process that symbolically links all members of the agnatic group to their common ancestral origin hearth. ${ }^{31}$ The acakaka provides the principal site for all sacrificial activities associated with the life-cycle events of the household and the maintenance of its health and wellbeing. ${ }^{32}$ At these times, kinsmen gather to provide sacrificial offerings (leura tei, ipilu tei) to group ancestors who are invited to attend the sacred hearth (acakaka na cuaré; to assemble at the hearth) within the house and participate in commensal union. For these events, portions of the sacrificial food might also be fixed to the outside perimeter of the house. The food is designed to feed ancestral shades reputed to be more threatening or unpredictable and who are said to stand outside and listen:

(Tava) koco pu na nehere (They) stand outside the walls,

Le upu na nehere behind and outside the house.

Their reported role is to ensure that only those who are entitled to participate in the ritual consumption of the sacrificial meat enter the house. Interlopers or strangers would be immediately identified and struck down. ${ }^{33}$

The primary relationship of an agnatic community with its ancestors is fundamentally mutually protective and interdependent (Schefold 2001). Just as people depend on ancestral blessings for their own health and wellbeing,

\footnotetext{
30 The converse of this idea is that sacrifices should be undertaken only at sites with direct ancestral connection to the clan members concerned.

31 These days, younger people, especially those living in Dili or Los Palos, might rely on the ritual hearths of their fathers or grandfathers for sacrificial blessing.

32 Households will also often fix a small forked stick (saka) above the entrance to the house, which they bless or 'feed' with a raw egg - leaving the upturned shell on one of the forks of the saka. These objects (leo'o utunatana) activate an ancestrally sourced protective perimeter around the house, which is said to ward off sickness and untoward malevolent influences. Food offerings to ancestors mirror social feasting practices and typically comprise a cooked and uncooked portion, the latter intended to be taken 'home' to feed those who were not able to attend ( $i$ camé la'a, tor apu una: a portion to take [home], for the many to eat together). 33 I have also heard the explanation that only the senior ancestors are invited into the house; those who have died more recently are thought to assemble outside and listen.
} 
so ancestors cannot exist without the continued ministrations of sacrificial offerings and the attention of their living descendants. ${ }^{34}$ The mutually implicated obligatory nature of this relationship provides at least one of the motivations for the continued enactment of sacrificial invocations within contemporary society. In a real sense, the survival of the ratu as a living, embodied group is dependent upon continued attention to its ancestors.

At the margins of the ancestral domain lie other inhabitants of the living environment that are considered inimical to healthy life and threaten the wellbeing of the household and family. These categories of being lie outside the ancestral realm proper but are nevertheless associated with or derived from the world of society and community. Their nature is more unpredictable and potentially harmful - an example being the shades of persons who suffer sudden and untimely deaths, who are murdered or commit suicide (ulao ucanu). Bad deaths such as these are highly inauspicious and the shades of the victims might be lost to the community of ancestors, becoming wild or threatening to the living (huma'ara kaparana: evil shades) (for comparison, see Fox 1973). Their presence might be signalled through dreams (ufarana) ${ }^{35}$ or upon hearing unusual sounds or movements in the dead of night (ula mosiku). They are thought to cause illness and sudden death when confronted.

In the same fashion, the unrestrained shades of miscarried foetuses might be associated with misfortune, injury or death among family members. These issues arise when a women miscarries or spontaneously aborts a foetus, which are referred to as 'fallen children' (moco $i$ fan). If this event occurs early in a pregnancy when a mother might not have been aware of her condition, the living being of the child ( $i$ hutu) is released into the world as an uncontrolled 'spirit' agent (huma'ara), causing accidents, slips or sudden deaths from falling among family members.

In response to the multiple possibilities and categorical ambiguities of the spiritual realm, ${ }^{36}$ Fataluku farming communities rely heavily on the mediating role of diviners and ritual leaders knowledgeable in the cultural techniques who can identify, direct and engage the complex elements of the living landscape that frame and influence embodied social life. All households and the extended family networks of which they are a part undertake a variety of domestic ritual performances and sacrificial engagements to facilitate and protect their own wellbeing. Collectively, however, they reside under the emplaced authority

34 Commenting on neighbouring Makassae practice, Lazarowitz noted that '[i]f one fulfils all the responsibilities owed to the ancestral spirits, life will follow a true and even course' (1980:181).

35 Fataluku contrast the 'spirit' (huma'ara) of the deceased with that of the living (ihutu). A person's ihutu living 'spirit' is said to be active and moving about when they dream.

36 I have not included discussion here of a further class of malevolent agents at work in Fataluku society, known as acaru (acare): witches and shape-changers who present as living human beings but are inherently dangerous and thought to cause illness and debilitating body disorders. 
of their respective 'lords of the land' whose cultural intimacy and enduring engagement with the living landscape, its cycles of life, death and renewal reaffirm the abiding connection of landowning clans and their co-dependent resident affinal allies. The moral authority of the autochthonous tei of place, combined over successive generations with a growing collectivity of human ancestral shades, merges into the composite and diarchic authoritative figure of the mua ocawa: mua hocawaru, the lord of the land.

\section{Landscapes of 'Spirit' Allies}

His hair was long and dishevelled, his beard thick and white, like that of a be'e na'in or spirit of the water. (Cardoso 2000:149)

Lautem is a diverse and heavily forested district, ${ }^{37}$ and this feature, along with the fringing coastal reefs and waters, provides an abundant array of foodstuffs and other resources that help sustain the domestic economy of Fataluku households. Local residents draw on a whole range of plant species - apart from firewood, timber and other building materials (bamboos, rotans and thatch for roofing) - for fibres, ropes, baskets, gums and vegetable supplements such as tubers, wild beans, leaf vegetables, resins, honey and forest fruits. An extensive pharmacopoeia is also recognised and drawn upon from the plant world (see Collins et al. 2007), ${ }^{38}$ while hunting is a popular activity throughout the year, and the use of various poisons, traps, spears and dogs provides a regular supply of game meat and seafood. ${ }^{39}$

A key principle of Fataluku landed authority is the protocol of seeking permission from the mua ocawa to access or engage in these various forms of resource extraction. The notion of permission here applies explicitly to outsiders, but the idea is inferred through interaction and consultation between affines and co-residents. Once again, the notion of permission extends to both the living human and the 'spirit' resident owners of the land in question.

\footnotetext{
37 In June 2007, as one of the final legislative actions of the former Fretilin Government, acting Prime Minister, Estanislau da Silva, was able to secure the legal establishment of the first national park in TimorLeste, which honours the memory of former Fataluku and Falintil resistence leader (1993-98) Nino Konis Santana, and creates an extensive multipurpose conservation reserve in Lautem (see McWilliam 2007b).

38 The forests of Lautem, particularly the mountainous Pai Cao region, provided a long-term sanctuary to armed Falintil guerillas, who benefited from a committed clandestine support network of Fataluku families. 39 This diversity of harvestable food includes fish (api), clams (saka), sea turtles (ipitu), sea eels (suanu), crabs (capuku) and sea urchins (tiri), as well as freshwater shrimp (asi) and turtles (veu), bats (maca), monkeys (lua), civet cats (loh), cuscus possums (acuru), deer (vaka), feral pigs (pai hoto) and birds (olo). Reef gleaning (meti fai, tono fai) for shellfish, seaweed and other edible marine creatures is practised along the foreshore during low tide (see Pannell, this volume).
} 
Fataluku describe the process of ritual invocation and divination directed to the invisible realm of teinu with the term ucuté, meaning to 'request something'. This is usually paired in formal Fataluku speech with the phrase lisé parité, to request agreement in the sense of obtaining permission. The phrase speaks to the relationship between customary landowners and the collective resident living forms in the land and its topographical features. The idea of requesting permission incorporates the related notion that generations of ancestors who preceded the living landowners have resided, worked and sweated in the landscape, and are now buried in the former settlements (lata paru) and abandoned garden sites (pala cenu) that are scattered around the clan country and its fallowed forests.

One example of acknowledgment is the casual practice of apportioning small offerings of food as gifts during meal breaks in the forest - a generic offering to unseen recipients as a sign of respect. More specific invocations might also be undertaken to enhance prospects for hunting or gathering wild foods at sites known to be inhabited by tei beings such as large trees (ete lafai), springs (iraina), caves (veraka ho acacapak) or other prominent topographical features. Active engagement with the indeterminate 'spirit' realm might be especially indicated when Fataluku pursue hunting or foraging activities beyond the settlements where forest 'spirits' (cat $[u]$ catu $)^{40}$ have the potential to befuddle or confuse the hunter, making game invisible or elusive, and where inspirited springs and watercourses (ira tei) can withhold their food resources (shrimp, crab, fish) from the fishers' gaze or net.

As a generic form of invocation or prayer for blessing, which can be used for securing forest game and other wild foods including marine resources, the following speech segment expresses this sense of humility and benefit. The reference is to wild bean but its application is broad:

e una pore'e naci'e,

et fo fon koron lari koron

unum ini ina inat la'an

le mara em ete asa taru asa

le meset zeu ho moco,

horu una, em nia tana polu pai
This food satisfies and fills,

raw bean and raw legume

a food portion given to us to take away

to take (to our house) as leaf and vegetable

(sweetening) the house of my wife and children eating together, our hands and feet replete.

40 Fataluku recognise a range of different cat catu spirit forms including those in large forest trees (cat catuserelai), spirits of the mountains (ili cata cat $[u]$ ) and those associated with the ocean (tahi cat cat $[u]$ ). 
Another expression of the intimate and mutually sustaining relationship between living community and 'spirit' realm expressed in the formal phrase 'lord of the land' (mua caoveli ocawa) is illustrated in the Fataluku cultural concept of curé, which I would gloss as a process of 'arising' or 'standing up'. The performative modality of curé might be mobilised in circumstances of dire threat or immanent danger to members of the ritual community. In the process - usually undertaken secretly at night - sacrificial invocations are enacted by senior clan members of the living 'land lords' to engage the collective living agency of the land and confront an enemy or threat. Only they have the authority and capacity to enact this process. The ritual words are designed to call the power of tei into action and to bring the silent living forces of the land into a state of defensive alertness:

Mua caoveli cure

Horo cao veli cure

Tua o cure pala o cure

Ete o cure taru o cure

Ete pata eni.

Ili moko eni
The land arises

The ground arises

Sugar palms and food gardens arise

Trees and vines arise

Trees and branches as well.

Rocky outcrops too.

By this ritual invocation of the taboo sphere (tei), the world becomes hot (timiné) and dangerous (malaru) $)^{41}$ for both the ritual community and the aggressors or opposing group. The former will receive the protection of the land from the mua hocawaru as long as they follow attendant moral codes including proper behaviour, abstaining from sexual intercourse ${ }^{42}$ and following relevant food proscriptions. Conversely, the intruding enemy will find themselves befuddled in the landscape as it turns against them. They will be unable to see their targets, spiked on thorns, bitten by insects, bruised by falling rocks, and their weapons also become ineffective:

$\begin{array}{ll}\text { Pata mucu elevé } & \text { The gun becomes cold } \\ \text { kanu mucu elevé } & \text { the gun stock becomes cold. }\end{array}$

In this way, the invocation of the tei of the land is activated through ritual speech to resist or attack (nacula) enemies of the resident landowning community.

41 The literal translation of malaru is 'bitter', but it carries the sense of danger and threat. The ancestors, calu ho papu, for example, are also said to be 'bitter'. This concept is one that might also have cultural associations with the healing power of indigenous medicines (larinete asa: literally, tree leaves) that are often bitter to taste, their efficacy deriving in part from the humoral association of bitterness and ancestral blessing. 42 Sexual relations are symbolically connected to fertility and ritual coolness - inimical to the heated state of warfare or violence in what might be considered a typical Austronesian cultural symbolic operator (Fox 1989:45). Breaking this injunction might cause the magical protection of the ritual form to fail. 
Land and Life in Timor-Leste: Ethnographic essays

Em neré naté

Directed to engage (the targets)

Em horopé em aporé told to shadow and pursue.

The manipulation of the retributive potential of the mua hocavaru allows for a range of applications. The process was reportedly invoked by 'all the ratu' during the 1975 military occupation of East Timor by Indonesian armed forces, and allowed the resistance fighters to hold out for years against prodigious odds. Pannell and O'Connor (2004) also discuss the ritual release of the 'president' tei at Titiru, Tutuala, during the violence and destruction that accompanied the popular referendum around independence in 1999. Following a request from then resistance leader, Xanana Gusmão, the local 'lord of the land' (Tutuala Ratu) sacrificed a pig at the stone tei and invoked the spirit to emerge from its hole to take action against the Indonesians (Pannell and O'Connor 2004:14).

There are also possibilities for mobilising the properties of the invisible mua hocavaru during the course of local hostilities or, for example, in longstanding disputes over unpaid bride-wealth (fai inu), thefts of buffalo or matters where group honour has been seriously impugned. The key idea is that the invisible world of tei may be invoked and directed by its living counterparts to consume or infuse (me a laku) the offending group or site with its poisonous intent. Each ratu has clan-specific tei connections that may be mobilised ritually to seek out and punish enemies.

When the task of the avenging mua ocawa is deemed complete, when justice has been meted out, a further sacrificial invocation is enacted to dispel the magical protective state, to close down its malevolent intent (nere $\mathrm{pa}^{\prime} i$ ) and return it to a condition of calm, life-giving coolness (fulehe $\mathrm{pa}^{\prime} i$ ). Similarly, as Pannell and O'Connor (2004:14) note: 'when the Indonesians left [Timor-Leste] the lord of the land returned to Titiru and sacrificed another pig to calm the tei down and entice it to enter its hole once again, satiated with food and drink, and the blood and flesh of the enemy.' In formal Fataluku speech, this ritual invocation may be expressed in the following way, accompanied with appropriate offerings and blood sacrifice:
Em uraceru
Ordered to return
em uraneru
called back
ma'u hin halivana nai
coming to the place of origin
hin hulutu'a nai
to the permanent resting place. 


\section{Landed Authority in a Binary Idiom}

In Lautem, as elsewhere in Timor-Leste, the initial euphoria of victory in the independence struggle has given way to a more subdued acceptance that economic hardship is not about to be alleviated any time soon. Under these circumstances, Fataluku communities are once again called upon to demonstrate their well-tested capacity for self-reliance and resilience. In that process, the cultural ideas and practices that draw upon the protection of the inspirited landscape continue to inform social life in multiple ways. They remain what they have always been: strategies and symbolic action designed to account for uncertainties in a world where any event might be significant and nothing can be left to chance (Pannell 2006:15).

These ideas are not, however, universally held in Fataluku society. The significant conversions to Catholicism, ${ }^{43}$ and the opportunities created by modernist secular education over more than two decades of Indonesian rule, have modified the degree of adherence to animistic ontologies. Many young people, in particular, who have forsaken the over-familiar confines of settlement life for wider opportunities in Dili and further afield, feel less constrained by ancestral conventions. Nevertheless, as one Fataluku colleague, a senior civil servant in Dili, commented to me: 'whether you believe or not doesn't really matter, but you shouldn't half believe because this can have serious consequences.' He then proceeded to tell me the apocryphal story of a man from Lorehe who decided to give up ancestral beliefs and practices by becoming Catholic and threw out his acakaka (sacrificial hearth). Not long after, his family began to suffer, his parents died suddenly, then his wife and his siblings, until he was the only one left, and people remonstrated with him, saying, 'Look what you have done by ignoring the calu ho papu'. He is then reported to have replied, 'Well, that is my sacrifice for God, but I will not return to those practices' - and then he died. The story is a lesson that confirms the self-fulfilling idea that if you forget your past and the names of the ancestors and discontinue your connection with them then you leave yourself unprotected from their blessings and are destined for oblivion.

The Fataluku living landscapes that I have outlined in this chapter and the relationship between the visible living 'lord of the land' and their autochthonous invisible counterpart (mua hocawaru) are ones that resonate with complementary concepts of land attachment and 'spirit' domains both in other areas of Timor,

\footnotetext{
43 Catholicism is estimated to have had just 17 per cent of the population of East Timor as adherents to the faith at the time of Indonesian occupation in 1975, but this had increased to upwards of 90 per cent by the late 1990s (Boyce 1995:79). This dramatic increase was in part driven by government insistence that Timorese follow the state-sanctioned moral philosophy of Pancasila, which required all Indonesians to follow an approved theistic religion, and the fact that the Catholic Church was also perceived as an institution of refuge against Indonesian military pro-independence repression.
} 
as noted in the Tetun concept of rai na'in, and widely across the Indonesian archipelago and the Austronesian-speaking world more generally (for example, Forth 1998; Molnar 2000). By way of comparison, I would cite Hicks' (2004:36) comments on the rai na'in among Tetun-speaking communities in Vikeke, where he notes that ' $[\mathrm{b}]$ oth spirits of the land and... water exercise a strong measure of control over the lives and aspirations of human beings', and where encounters can bring great good fortune (wealth, physical prowess or invulnerability) but equally the prospect of infertility, sickness, insanity and death. In a similar fashion but with more historical depth, van Wouden, writing on northern Tetun populations and following Grijzen's earlier 1904 report, makes the observation that

the term 'lord of the land' also occurs among the forms of address applied to a ruler. These are: nai lulik, sacred lord; rai na'in, lord of the land; and ata na'in, lord the people. Rai na'in are also earth-spirits, whose worship occupies such an important place in religious life. (1968:49)

A similar set of ideas extends well beyond Timor. Wessing, for example, has described a comparable complex on Java in remarkably similar terms. He notes that Javanese speak of 'the spirits of place as penguasa, the ones who are in authority or control', and he interprets the status of the 'lord of the soil' (tuan tanah in Indonesian) as the divinisation of the energies that produce the fruits of nature by which the resident community is sustained in its locality (Wessing 2006:18). In these terms, the blessings that derive from this divinisation are also extended to the living counterpart of the tutelary spiritual 'lord of the land', which adds to and reproduces their status and authority.

More than this, Wessing has interpreted the relationship between living, human settlers and their spiritual counterparts as one that 'socializes the symbolically wild realm of nature spirits' and renders it conducive to human settlement. Through ritual offerings and invocations, the spirits acquiesce to the occupation of their land by human beings and become the objects of cult celebration. 'Ensnared by sacrifice, they are then bound to render assistance' (Wessing 2006:34). He concludes that the person who controls the spirit is usually the one who opens the area, the founder of the village or their descendants. Their demonstration of spiritual authority and control of the 'spirits' of the land place these figures and their inheritors in leadership positions of their communities.

This doubly constituted notion of the lord of the land is also strongly suggestive of two further possibilities or interrelationships that have long been recognised as foundational concepts for Austronesian ritual polities. The first of these connections is the widespread theme of diarchy and diarchic models of politicoritual leadership (see Cunningham 1965; Fox 1989). Across the island of Timor itself, the historical pattern of indigenous governance was one composed of a 
double ruling centre usually distinguished by gendered symbolism. Leadership of the domain was commonly shared between a ritual and political ruler (Schulte Nordholt 1971) in which landed spiritual authority and executive political power were constituted asymmetrically and diarchically. In these realms, a symbolically female, ritual lord, on receipt of harvest gifts and other tribute from the land, reciprocated with ritual blessings that ensured continued fertility and abundance for the people. The symbolically masculine counterpart was responsible for executive political leadership, the organisation of the people living within the domain and the defence of the realm itself. Over centuries of Portuguese and Dutch colonial attempts to manipulate and control Timorese political life, much of the delicate and dynamic balance of these diarchic patterns of authority has been disrupted and undermined, but they remain informally evident in many areas of Timor where customary protocols require their explicit articulation within clan organisation or in the rhetorical narrative structures that frame and support contemporary village (suco) authority (see Freidberg 1989; Traube 1986 ).

The diarchic mode of leadership is similarly expressed in that other pervasive theme of landed authority in Austronesian societies: the mythology of the stranger king. This cultural motif and its narrative variants ${ }^{44}$ typically revolve around an original transfer of power to an immigrant prince signified by the surrender, usually in marriage, of a native or autochthonous woman of rank (Sahlins 1985:87). The concept is one eminently compatible with, for example, the prehistoric maritime expansion of Austronesian settler communities across insular Asia and the Pacific (Bellwood 1996; Siikala 1996), as it is with contemporary Austronesian claims to legitimacy and contested cultural sovereignty over local jurisdictions (for example, Graham 1996). In a variation on the theme of the stranger king, Fox has explored the complex recursive patterns expressed by the process of 'installing the outsider inside'. The idea speaks to the historical processes of displacement in the Austronesian world of Timor whereby influential or powerful outsiders become chiefly rulers through distinctive cultural processes of incorporation (Fox 1995). ${ }^{45}$

These three foundational mythologies of emplaced authority - the lord of the land, the diarchic polity and the stranger king-are cultural themes that ramify across Timor and the Austronesian world. In their rich and diverse local renditions, they each appear to represent reflections or refractions of the same guiding principle - namely, the discourse of origins expressed as contested

\footnotetext{
44 A variant of this mythology is that of the returning younger brother who is accorded political power over his 'elder siblings' who have remained in place at the centre of the world tending to their ritual responsibilities (see, for example, Traube 1986).

45 Similarly, Sahlins has recently argued that the elemental relationship between affines is the archetype for stranger-king politics: 'the affinal relationship is the experiential ground cum social enactment of people's dependence for their own existence on external sources they do not control' $(2008: 195,196)$.
} 
precedence (Vischer 2009), whereby the spiritual or autochthonous element is temporally prior, but submits - literally gives ground-to a subsequent political authority, thus forming a complementary and composite unity. The diarchic principle of authority is one that signifies and celebrates the negotiated and recursive patterns of accommodation between emplaced autochthonous communities and settler immigrants that have informed the dynamic histories of island societies for generations (for comparison, see Forth 1989; Freidberg 1989). The finding is consistent with Fox's exploratory study of Austronesian ideas of rule and of the dialectic relationship of political power and spiritual authority to the categories of 'inside' and 'outside'. In comparative Austronesian terms, political orders are never constructed entirely from 'within' but are constituted from both internal and external origins (Fox 1995:18). For Fataluku society, the ritually mediated and sustained landed authority of the composite lord of the land - the mua ocawa-provides one cultural version of this fundamental and life-affirming understanding.

\section{Acknowledgments}

Research for this chapter has been pursued intermittently over the period 2002-09 under the auspices and support of The Australian National University. Funding has also been provided by an Australian Research Council Discovery Grant (2005-2008), entitled, Waiting for Law: Land, custom and legal regulation in East Timor. My thanks extend to many patient Fataluku ethnographic advisers, especially Anita Ximenes, Almeida Fernandes Xavier, Fernando Santana, Sidonio da Cruz, Mario dos Santos Loyola, Amando Lopes (dec), Rikardo Lopes, Francisco Valela, Edmundo da Cruz, Robella Mendez, Carmeneza Dos Santos Monteiro and Justino Valentim. Thanks also to reviewers for comments and suggestions. 


\section{References}

Bellwood, P. 1996, 'Hierarchy, founder ideology and Austronesian expansion', in James J. Fox and Clifford Sather (eds), Origins, Ancestry and Alliance: Explorations in Austronesian ethnography, Research School of Pacific and Asian Studies, The Australian National University, Canberra, pp. 18-40.

Bird-David, N. 1999, “Animism" revisited: personhood, environment and relational epistemology', Current Anthropology, vol. 40, pp. 67-91.

Boyce, D. (compiler) 1995, Timor: where the sun rises over the crocodile's tail: a collection of environmental, historical and cultural notes, Unpublished manuscript, Dili.

Campagnolo, M. L. O. 1975, L'habilitation des Fataluku de Lorehe (Timor Portugais), Thèse de Doctorat de 3ème cycle, Academie de Paris, Ecole Pratique des Haute Etudes, Université René Descartes, Paris.

Cardoso, L. 2000, The Crossing: A story of East Timor, Granta Books, London and New York.

Collins, S., Martins, X., Mitchell, A., Teshome, A. and Arnason, T. 2007, 'Fataluku medicinal ethnobotany and the East Timorese military resistance', Journal of Ethnobiology and Ethnomedicine, vol. 3, no. 5, Published online 22 January.

Cunningham, C. E. 1965, 'Order and change in an Atoni diarchy', Southwestern Journal of Anthropology, vol. 21, pp. 359-82.

Forbes, H. O. 1989 (1885), A Naturalist's Wanderings in the Eastern Archipelago, Oxford University Press, Singapore.

Forth, G. 1989, 'The Pa Sése festival of the Nagé of Bo'a wae (central Flores)', in C. Barraud and J. D. M. Platenkamp (eds), 'Ritual and socio-cosmic order in eastern Indonesian societies', Bijdragen tot de Taal-, Land-en Volkenkunde, vol. 145, no. 4, pp. 502-19.

Forth, G. 1998, Beneath the Volcano: Religion, cosmology and spirit classification among the Nage of Eastern Indonesia, KITLV Press, Leiden, Netherlands.

Fox, J. J. 1973, 'On bad death and the left hand: a study of Rotinese symbolic inversions', in R. Needham (ed.), Right andLeft: Essays on dual symbolic classification, University of Chicago Press, London and Chicago. 
Fox, J. J. 1989, 'Category and complement: binary ideologies and the organization of dualism in eastern Indonesia', in David Maybury-Lewis and Uri Almagor (eds), The Attraction of Opposites: Thought and society in a dualistc mode, University of Michigan Press, Ann Arbor, pp. 33-56.

Fox, J. J. 1995, Installing the outsider inside: the exploration of an epistemic Austronesian cultural theme and its social significance, [Revised draft], Paper presented at the first Conference of the European Association for Southeast Asian Studies: Local Transformations and Common Heritage in Southeast Asia, 29 June - 1 July, Leiden University, Netherlands.

Freidberg, C. 1989, 'Social relations of territorial management in light of Bunaq farming rituals', in C. Barraud and J. D. M. Platenkamp (eds), 'Ritual and socio-cosmic order in eastern Indonesian societies', Bijdragen tot de Taal-, Land-en Volkenkunde, vol. 145, no. 4, pp. 548-62.

Graham, P. 1996, 'Enacting sovereignty: sacrifice and the power of outsiders in Lewolema, Flores', in S. Howell (ed.), For the Sake of Our Future: Sacrificing in eastern Indonesia, Research School CNWS, Leiden, pp. 148-75.

Harvey, G. 2006, Animism: Respecting the living world, Columbia University Press, New York.

Hicks, D. 2004, Tetum Ghosts and Kin: Fertility and gender in East Timor, [Second edn], Waveland, Long Grove, Ill.

Hicks, D. 2007, 'Younger brother and fishing hook on Timor: reassessing Mauss on hierarchy and divinity', Journal of the Royal Anthropological Institute, vol. 13, pp. 39-56.

Hubert, H. and Mauss, M. 1964 [1888], Sacrifice: Its nature and function, W. D. Halls (trans.), Chicago University Press and Cohen and West Ltd, Chicago and London.

King, M. 1963, Eden to Paradise, Hodder \& Stoughton, London.

Lazarowitz, T. F. 1980, The Makassai: complementary dualism in Timor, PhD thesis, State University of New York, New York.

McWilliam, A. R. 1999, 'From lord of the earth to village head: adapting to the nation state in West Timor', Bijdragen tot de Taal-, Land-en Volkenkunde, vol. 155, no. 1, pp. 121-44.

McWilliam, A. R. 2001, 'Prospects for the sacred grove: valuing lulic forests on Timor', Asia Pacific Journal of Anthropology, vol. 2, pp. 89-113. 
McWilliam, A. R. 2002, Paths of Origin, Gates of Life: A study of place and precedence in southwest Timor, KITLV Press, Leiden, Netherlands.

McWilliam, A. R. 2007a, 'Austronesians in linguistic disguise: Fataluku cultural fusion in East Timor', Journal of Southeast Asian Studies, vol. 38, no. 2, pp. 355-75.

McWilliam, A. R. 2007b, 'Customary claims and the public interest: on Fataluku resource entitlements in Lautem', in Damien Kingsbury and Michael Leach (eds), East Timor: Beyond independence, Monash Asia Institute Press, Melbourne, pp. 165-78.

Meitzner Yoder, L. 2003, Custom and conflict: the uses and limitations of traditional systems in addressing rural land disputes in East Timor, Discussion Paper prepared for a regional workshop on Land Policy and Administration for Pro-Poor Rural Growth, Dili.

Molnar, A. K. 2000, Grandchildren of the Ga'e Ancestors: Social organisation and cosmology among the Sara Hoga of Flores, KITLV, Leiden, Netherlands.

National Census of Population and Housing in Timor-Leste 2004, Direcção Nacional de Estatística, Dili, Timor-Leste.

O'Connor, S. and Pannell, S. 2006, Cultural heritage in the Nino Conis Santana National Park, Timor Leste: a preliminary assessment, Unpublished report.

Pannell, S. 2006, 'Welcome to the Hotel Tutuala: Fataluku accounts of going places in an immobile world', Asia Pacific Journal of Anthropology, vol. 7, no. 3, pp. 203-19.

Pannell, S. and O'Connor, S. 2004, Where the wild things are: an exploration of sacrality, danger and violence in confined spaces, Paper presented at the Society for American Archaeology Sixty-Ninth Annual Meeting, Montreal, pp. 1-19.

Pederson, M. A. 2001, 'Totemism, animism and North Asian indigenous ontologies', Journal of the Royal Anthropological Institute, vol. 7, no. 3, pp. 411-27.

Peterson, N. 2006, A sentient landscape? Animism, metaphor and symbolic action in Australia, Paper presented at the American Anthropological Association Conference.

Poirier, S. 2005, A World of Relationships: Itineraries, dreams and events in the Australian Western Desert, Toronto University Press, Toronto.

Sahlins, M. 1985, Islands of History, University of Chicago Press, Chicago. 
Sahlins, M. 2008, 'The stranger-king or, elementary forms of the politics of life', Indonesia and the Malay World, vol. 36, no. 105, pp. 177-99.

Sansom, B. 1993, The Warai people and the Wagait land dispute: an anthropological report to the Northern Land Council, Darwin.

Schefold, R. 2001, 'Three sources of ritual blessing in traditional Indonesian societies', Bijdragen tot de Taal-, Land-en Volkenkunde, vol. 157, no. 2, pp. 359-81.

Schulte Nordholt, H.G. 1971 The Political System of the Atoni of Timor, Nijhoff, The Hague.

Siikala, J. 1996, 'The elder and the younger-foreign and autochthonous origin and hierarchy in the Cook Islands', in James J. Fox and Clifford Sather (eds), Origins, Ancestry and Alliance: Explorations in Austronesian ethnography, Department of Anthropology, Comparative Austronesian Project, Research School of Pacific and Asian Studies, The Australian National University, Canberra, pp. 41-54.

Traube, E. G. 1986, Cosmology and Social Life: Ritual exchange among the Mambai of East Timor, University of Chicago Press, Chicago.

van Wouden, F. A. E. 1968, Types of Social Structure in Eastern Indonesia, Nijhoff, The Hague.

Vischer, M. P. (ed.) 2009, Precedence: Social differentiation in the Austronesian world, ANU E Press, Canberra.

Viveiros de Castro, E. 1998, 'Cosmological deixis and Amerindian perspectivism', Journal of the Royal Anthropological Institute, vol. 4, no. 3, pp. 469-88.

Wessing, R. 2006, 'A community of spirits: people, ancestors and nature spirits in Java', Crossroads, vol. 18, no. 1, pp. 11-111. 